\title{
Trainee's Life and Sense of Work: The Labor and its Representations
}

\section{Carlos Cesar Ronchi, Natália Queiroz da Silva Moura, Nehemias Pinto Bandeira, Ricardo Daher Oliveira, José Samuel de Miranda Melo Júnior}

Brazil

\begin{abstract}
This research presents a construct about the sense of work aiming to expand knowledge on the phenomenon. It predisposes to present the facets on the relation between the sense of work and society in the liquid contemporary world. In this article, it is intended demonstrating several sides of work, emphasizing the pleasure and suffering, which can be seen as factors that influence the feelings. In this context, it is aimed demonstrating the main causes that can affect the health and quality of life at work. This article also aims to identify which sense the trainees attribute to their work, from conceptions about the phenomenon studied, and has as problematic the following questioning: how the trainees' lack of commitment causes impact in the sense of work? In order to complement the compression of the phenomenon studied, a research has been carried out with trainees from Companhia de Saneamento Ambiental do Maranhão - CAEMA, having as basis a questionnaire, in which several dimensions on the sense of work are involved. The research evinces with greater predominance, that the sense, that the investigated people find in the performed work is related to the learning requirements, evolution, and knowledge construction.
\end{abstract}

Keywords: Work. Sense of Work. Society. Quality of Life.

\section{INTRODUCTION}

The present article has proposed a reflection about work and its sense, in the perception of the trainees from Companhia de Saneamento Ambiental do Maranhão - CAEMA. It had as purpose to understand how trainees attribute a sense to the work carried out. The main approach was doing an analysis between sense of work and liquid contemporary world: pleasure, suffering, and health and quality of life at work. The relation between Society and Work is directly connected to the individuals' perception about this phenomenon. It is taken into account that the sense of work is related to the social environment in which the individual is inserted. The labor has occupied an outstanding role in the society, since individual spends long hours in the organizational environment.

Each subject defines work and its sense in many ways, since different activities are proposed to them, becoming, many times, fundamental piece to compose the organizational environment, that can be transformed into a factor of social recognition; in this perspective, work is defined according to its necessities and desires in intention to reach objectives and goals being proposed (DEJOURS, 2004). The comprehension of sense, which individuals attribute to the activities carried out, is related to the challenges, since they have distinct skills, sensations and feelings. The guidelines, which involve the work, might present feelings of pleasure and suffering, having as consequences some factors that might influence in health and quality of life.

On the basis on the foregoing and considering the relevance of the theme, this article has collected as research problematic the following questioning: "How the trainees' commitment causes impact in the sense of work?"For such questioning, it was needed developing a bibliographic review and use of observation arrangements or information collection, which allowed that the thematic investigated could reach the research general goal, namely, identifying which sense the trainees attribute to their work, from conceptions about the phenomena studied.

\section{SOCIETY AND LIQUID CONTEMPORARY WORLD}

The sense of work is directly related to the social environment where the individual is inserted, who, when developing an activity, attributes values to what it carries out, being they linked to the society, 
individual and sense of work. About this basis, Freitas (2000, p. 7) reports that "organizations must be understood within a specific social space and period, constituting, therefore, in a socio-historic format". The organizations are inserted in the social space, highlighting among the actors, because worked started to be seen as a factor of social recognition.

The evidences indicate that, in the contemporaneous world, the organizations impose models and standards, in which the accelerated workload constantly remits to the individuals a routine of work and more and more intense commitment. In this exposed, for Prestes Motta (1981, p. 37) "the organization reproduce itself, thus, while social system that includes the psychological and individual working of its members. The organizational system articulates itself, therefore, with the system of personality and values of its participants". From this understanding, Ronchi (2015, p. 74) expresses that "the facet of molding the worker behavior, adapting it to the organizational needs and goals, reinforces a social control". This control becomes the repository of a big set of collective sedimentations that establishes a reality of uncontrollable dynamism. There is a commitment of the individual's social life and about this ground, Lipovetsky (2004, p. 75) defends "the accumulation of organization problems and management of social time, as well as the new administration demands, reorganization, flexibility by bias of customized devices, with view to the promotion of time adjusted to the individual needs".

In the organizational context, the individual, many times, is seen as a mere generate factor of profits, because the importance that it has in the work environment is put aside. Based on this argument, Clegg (1996, p. 56) defines that "people do not reduce themselves to be only manpower or creator of meanings. They are, at the same time, subjected to both, that is: they define themselves as manpower and at the same time as bearer of different social identities, multiple and interconnected". In the same line, Ronchi (2010) demonstrates that the need of involving people in the process is very discussed, of considering them as fundamental, but what is observed is that, in the majority of organizations, it is only possible to see the human being in a fragmented and alone way.

The transformations inherent to the work environment directly affect the individual in the organizational scenery; in this reality, therefore, the practices of Liquid Modernity are inserted, because each situation gradually adapt to the models that, many times, are imposed by society. In this dynamics, Bauman (2001, p. 15) defines that "the modernity starts when the space and time are separated from practice of life and among them, and thus can be theorized as distinct categories and mutually independent from strategy and action". Given the evidences, society and modernity influence the life, which may affect the sense that the individual remits to the work. In this exposed, Debord (1997, p. 13) expresses that "the whole life of societies, in which modern conditions of production govern, it is presented as an immense accumulation of spectacles. Everything that was directly experienced became a representation".

\section{SENSE OF WORK IN THE CONTEMPORNEOUS SOCIETY}

The sense of work started to be seen as a challenge for comprehension of influences that involve the individuals' behavior in the organizational environment and, this perspective, for Morin (2001, p. 8) "nowadays, to understand the senses of work, is an important challenge for the administrators, in view of the multiple transformations that have reached the organizations". In this exposed, Tolfo and Piccinini (2007, p. 40) express that "and reproduced, that interacts with different personal and social variables and influence the persons' actions."

The work can be seen in many ways and the organizational environment is a factor that influences the sense that the individual attributes to the activities carried out. In this context, Tolfo et al. (2011, p. 184) affirm, "The sense concerns the activity of the subject, its relationship with the way how the phenomena of life and goals are apprehended by its conscience". In view of the above stated, Ronchi (2010, p. 34) points that "the sense of work may be associated when it helps the individual to discover and form its identity, since the accomplishment feeling is an important factor for giving sense to the work".

When developing its tasks, the individual is shrouded in an organizational world, composed by different features, which portrait in parts the work environment. Based on this argument, Gaulejac (2007, pp. 154-156) contextualizes the features of work, being classified in five, as following exposed: 
Trainee's Life and Sense of Work: The Labor and its Representations

Table1. Elements that Characterize Work

\begin{tabular}{|c|l|}
\hline Features & \multicolumn{1}{c|}{ Definitions } \\
\hline Act of work & $\begin{array}{l}\text { It is more and more connected to the accomplishment of a concrete product or specific } \\
\text { job. }\end{array}$ \\
\hline Remuneration & It is not in fact connected to the quality or quantity of supplied work. \\
\hline Collective of work & $\begin{array}{l}\text { It is no longer bearer of stable ties. It does not longer establish a sense of belonging in } \\
\text { duration. }\end{array}$ \\
\hline Work organization & $\begin{array}{l}\text { In a world of permanent reorganization, in which flexibility becomes a dominant rule, } \\
\text { the very notion of organization, as an arrangement that assures the coherence and } \\
\text { stability of a set, becomes fluid. }\end{array}$ \\
\hline Value of work & $\begin{array}{l}\text { It is no longer connected to the work quality, of goal accomplished, of concrete } \\
\text { activity. }\end{array}$ \\
\hline
\end{tabular}

Source: Adapted from Gaulejac (2007, pp. 154-156).

The sense attributed to the activities, which involves the individual's daily life, is individually developed in many ways and distinct sensations. In this exposed, Tolfo and Piccinini (2007, p. 40) make the following approach "work is rich of individual and social sense, is a way of production of life of each one when providing subsistence, creating existential senses or contributing to the structuring of identity and subjectivity". Each subject has distinct skills, which are improved, consequently, the sense that the individuals attributes to its work became fundamental piece for development both organizational and personal. Based on this argument, Morin (2001, p. 14) argues that a work has sense if efficiently done, if conducting something, if benefits other persons, if it corresponds to the interests and to the competencies of people, if it allows to learn, fulfil itself 1 and overcome itself, and if it allows to express and exercise its power.

The individual's behavior and development, in the environment in which is inserted, cause direct impacts in the organizational environment. In this context, Ronchi (2010) enunciates that, through its experiences, values, beliefs and assumptions, each individual gradually creates the work particular meaning. The meaning of work is discriminated in three great domains, that Bastos, Costa and Pinho (1995, pp. 22-23) classify in centrality of work, the work social standards and the results and goals valued in the work. Centrality of work is defined as the general importance level that the work has in the individual's life in a certain moment. Work social standards: consist of the relationship that the individual establishes with the standards socially accepted about the work. Results and goal valued at work: relate themselves with the finalities that the work activities have for the individual.

It is necessary developing capacity of self-knowing oneself, since it is essential building a relationship of respect among the subjects. Thus, a work with sense is directly reflected in the company's endresult. In this premise, for Dejours (1992, p. 40), "the lack of sense of the individual task and the knowing of the collective task sense, take its true psychological dimension only in the men's division or separation". To better understand the individual's behavior, in the intern environment, Dejours (2004) expresses that the work is what that implies, from the human point of view, the fact of working: gestures, know-how to do, a body engagement, mobilization of intelligence, capacity to reflect, interpret and react to the situations; is the power of to feel, to think and to invent.

The meanings and senses of work are perceptible only with direct contact when carrying out activities, in which the relation between carried out work and individual are fundamental pieces for the development of the sense of work. In this performance, Coutinho (2009, p. 193) reports that "considering the dialectic relation between senses and meanings, the analysis the senses produced by the subjects must always consider their relations with the meanings collectively produced and viceversa".

\section{Work: Pleasure and Suffering}

The guidelines of a social environment trace a world of transformations in the work dimensions, since the organizations are going through many structural changes. Based on this assumption, Morin (2001, p.8) explains that "the moments of organizational transformation constitute, potentially, an opportunity to reorganize the work in such way that the quality of life and organizational effectiveness be improved". For this purpose, the search for efficiency may become a worry generator for the individual, and may thus cause some kind of impact in the behavior. "Technological and organizational changes of work accelerate the worry about the behavior in the worker's individual and social plan". (SANTOS et al., 2010, p. 251). 
Work is considered a way of social interaction, because relationships are developed and built in it, however, tracing its own trajectory in the organizational environment. Based on the points made above, Gaulejac (2007, pp. 122-123) enunciates that "it is up to each one to give proofs of its utility, its productivity, its profitability and, therefore, demonstrate that it knows to keep its place and, when necessary, do its own place". In this conception, "work is also a possibility of social insertion, due to the worker meeting with many others within the same space or out of it, far from just being an activity to be also a way of social relationship" (LIMA et al. 2013, p. 49).

The labor has occupied great part of the individual's time, because each subject, when developing its activities in the environment in which it militates, even being routine, manifest distinct sensations. In this context, Dejours (2004, p. 28) expresses that "work defines itself as being what the subject must add to the prescriptions to reach goals that are destined for it". Based on the points made above, Ronchi (2010) explains that, work can be considered as one of the fundamental means that declare the individual to its social-human nature.

In this sense, work became a pleasure generator source, self-fulfillment or even unhappiness and uncertainties. About this ground, Morin (2001, p. 16) defines that "pleasure and the feeling of fulfillment that can be obtained in the execution of tasks give sense to the work". In the organizations, the meaning that the individual attributes to its activity may cause some kind of impact in the work environment. In this conception, Bastos, Pinho and Costa (1995, p. 22) defend that "the subjective meaning of work can be conceptualized as a cognitive structure, a schema, which has strong impact on the perceptions, evaluations, attributions, and on the individual's own behavior at work".

The work has a downside, and may trigger a series of problems, becoming a suffering generator factor; Ronchi (2010) affirms that the work, for the majority, has turned into torture, since organizations do not worry about individuals' well-being; an aspect, that directly influences the development of activities, is the organization of work. In this dynamics, for Ladeira (1996, p. 65) "the organization of work represents, thus, the basic input for a discussion about pleasure and suffering in its context, because it realizes possibility for work become balanced or exhausting, source of fulfillment or alienation for the one who carries it out". For a better understanding of the foregoing, the following chart provides a view of the concepts that involve work and suffering, from a theoretical approach among the authors.

Table2. Definition of work and suffering

\begin{tabular}{|c|l|}
\hline Authors & \multicolumn{1}{c|}{ Definitions } \\
\hline $\begin{array}{c}\text { Dejours; } \\
\text { Abdoucheli }\end{array}$ & $\begin{array}{l}\text { Suffering is unavoidable and ubiquitous. It has roots in the singular history of all } \\
\text { subject, without exception. It echoes in the theater of work, when entering a } \\
\text { relationship whose complexity we have already seen, with the organization of work. }\end{array}$ \\
\hline Gaulejac & $\begin{array}{l}\text { It generates behavior of addition, cultural stress, invasion feeling, against which it is } \\
\text { difficult to fend off, and sufferings that the individual hides; on the other hand, if they } \\
\text { were expressed, would be targeted. }\end{array}$ \\
\hline Chanlat & $\begin{array}{l}\text { The contemporaneous organizations have influence more and more on the individual } \\
\text { ducting, on nature, socioeconomic structures and culture, what can take them to turn } \\
\text { into key-elements of societies, contributing in a way to build a world social order. }\end{array}$ \\
\hline $\begin{array}{c}\text { Guimarães; } \\
\text { Siegrist and } \\
\text { Martins }\end{array}$ & $\begin{array}{l}\text { The effort at work is spent as part of a process, of a socially organized exchange for } \\
\text { which society massively contributes in terms of rewards. }\end{array}$ \\
\hline Ronchi & $\begin{array}{l}\text { The organization, in a general way, should worry a lot about its workers' health, since it } \\
\text { seems paradoxical that they want increase their results and do little, in practice, to } \\
\text { minimize suffering at work. }\end{array}$ \\
\hline
\end{tabular}

Source: Adapted from Dejours and Abdoucheli (1994, p. 137), Gaulejac (2007, p. 218), Chanlat (1996, p. 40), Guimarães; Siegrist and Martins (2004, p.71), Ronchi (2010, p. 42).

The organizations seek skilled professionals, since there was an increase on requirements; the individual seeks the professional recognition. "The work should no longer be reduced only to physical, chemical and biological pressures [...]. It is necessary, besides, considering the organizational dimension at work, that is, the division of tasks and production relations" (DEJOURS, 1994, p. 47).

Based on the presented, the phenomena pleasure and suffering at work have several facets, thus exposing the two sides of this context, which comprises the organizational environment. In this 
dynamics, Chanlat (1996, p. 29) reports that "in all social system, the human being has relative autonomy. Marked by its desires, aspirations and possibilities, it has a level of liberty, knows what can reach and what price will be willing to pay to get it in the social plan". Considering this phenomenon, Ronchi (2010, p. 48) declares, "Suffering may become instrument of a modification in the organization of work or generate a process of alienation and conservatism".

\section{QUALITY OF LIFE AND WORK: IMPACTS IN THE WORKER}

The study of quality of life at work happened due the power of influence of the individuals' behavior in the organizational context and, mainly, due to cause some kind of interference in the performance of tasks. In this context, Dejours (1992, p. 45) express that "little are the male and female workers who can organize leisure according to their desires and needs". Many times, the individual is trapped in the tiring routines or even to a work environment that is not propitious to carry out certain tasks. In this dynamics, Ronchi (2015) defends that the quality of life at work is an extensive and committed comprehension of the work life conditions, which includes aspects of well-being, health guarantee and social, physical and mental security, training to carry out tasks with security, and good use of personal energy.

The work conditions are preponderant factors for efficient performance of activities that involve the work environment. Dejours (1992, p. 25) summarizes these conditions into two: By conditions at work: it is needed to understand, before all, the physical environment (temperature, pressure, noise, vibration, irradiation, altitude, etc), the chemical environment (manipulated products, vapors and toxic gases, dust, smoke, etc), the biological environment (virus, bacteria, fungi, parasites), hygiene and security conditions, and the workplace anthropometric features. By work organization: we assign the work division, task content (as far as it derives from it), the hierarchical system, the command modalities, the relations of power, the questions of responsibility, etc.

Due the search for meeting deadlines, in a short time, individuals can experience a series of physical and psychological problems, because there are a lot of accountability in relation to the search for excellence of carried out work. The lack of work conditions may develop some kind of psychological disorder, among them: professional neurosis. Aubert (1993, p. 85-86) teaches us "professional neurosis is a state of disorganization persistent of personality, with consequent installation of a pathology, linked to a certain professional or organizational situation".

The health and quality of life may be affected by numerous causes that reach the individual as well as its resourcefulness at the work environment. The following table shows, in the authors' perception, some of the main factors that influence health and quality of life at work.

Table3. Main causes that influence health and quality of life at work

\begin{tabular}{|c|c|l|}
\hline Causes & Authors & \multicolumn{1}{c|}{ Definition } \\
\hline $\begin{array}{c}\text { Psychic } \\
\text { workload }\end{array}$ & Dejours & $\begin{array}{l}\text { The psychic workload seems to have a status aside. It is not a behavior } \\
\text { juxtaposed to the physical load and to the nervous load, as far as it is able to } \\
\text { modify, in a sense or other, the global resultant of the workload. }\end{array}$ \\
\hline $\begin{array}{c}\text { Fear and } \\
\text { work }\end{array}$ & Dejours & $\begin{array}{l}\text { The fear is present in all kinds of professional occupations, even in repetitive } \\
\text { tasks and in office works, where it seems occupying modest role. }\end{array}$ \\
\hline $\begin{array}{c}\text { Excessive } \\
\text { workload }\end{array}$ & $\begin{array}{c}\text { Sampaio; } \\
\text { Guimarães }\end{array}$ & $\begin{array}{l}\text { Each worker, dependent on its education level, experience, gender, age, } \\
\text { among other aspects, can differently feel the workload. }\end{array}$ \\
\hline $\begin{array}{c}\text { Professional } \\
\text { Stress }\end{array}$ & Aubert & $\begin{array}{l}\text { Professional Stress is the disturbance process engendered in the individual by } \\
\text { its excessive mobilization of adaptation for confrontation of requests from its } \\
\text { professional environment, requests that overcome current, physical and } \\
\text { psychic capacities of this individual. }\end{array}$ \\
\hline $\begin{array}{c}\text { Stressful } \\
\text { environment }\end{array}$ & Ronchi & $\begin{array}{l}\text { With professional environment more and more physically and emotionally } \\
\text { stressful, it is realized the erosion of dignity and desire and, consequently, } \\
\text { they may affect individuals' health. }\end{array}$ \\
\hline
\end{tabular}

Source: Adapted from Dejours (1994, pp. 28-29); Dejours (1992, p. 36); Sampaio; Guimarães (2004, p. 92); Aubert (1993, p. 85); Ronchi (2010, pp. 103-104).

The organizations are responsible for the subject's health and quality of life in the work environment, considering that it is fundamental part to compose the organization, being part of its development. In this conception, Thiry-Cherques (2004, p. 13) reports that "the ways to organize are victimizing not only the worker, but the work while activity socially established". On the basis on the foregoing, 
health and quality of life at work are connected, thus, it is necessary to establish condition of life in the work environment, which be acceptable. In this exposed, for Ronchi (2010), the quality of life at work must consider the satisfaction of the individual's needs and expectations, establishing that health and quality of life are interdependent concepts.

\section{RESEARCH METHODOLOGY}

The research is related to theories that involve the sense of work and its dimensions, having as basis a questionnaire with 89 questions. The questionnaires were applied along with trainees from Companhia de Saneamento Ambiental do Maranhão - CAEMA - between July and August/2015, aiming to identify which sense they attribute for the work carried out. Currently, the company staff comprises 49 trainees, from which 44 of them were researched, characterizing, practically, a census survey, since the sample constitutes $89.8 \%$ of the universe.

It was necessary using methodology of basic research, as to its nature, and, as to the goals, the research is exploratory and descriptive methodology; the methodology applied was quantitative approach. It is used application of questionnaires with scope in Likert scale, with the following options of answers: I totally disagree $=1$, Ipartially disagree $=2$; I don't agree neither disagree $=3$; I partially agree $=4$ andI totally agree $=5$. The nature of the research is basic, on account of being a scientific research for construction of new knowledge; in this dynamics, Cervo, Bervian and Silva (2007, p. 60) express that, "in the pure or basic research, the researcher has as a goal the expertise, seeking to satisfy an intellectual need by means of knowledge". With respect to the research goals, it is exploratory and descriptive, aiming to obtain greater approach on the phenomenon studied. When carrying out questionnaire application, it was used quantitative approach, because statistic methods were used for better develop the treatment and analysis of data.

\section{RESUltS AND RESEARCH ANALYSIS}

When developing the research, it was applied a questionnaire with closed questions, discriminated in socioeconomic information and eight dimensions that involve questionings about work and its sense. The questionnaires were applied with the trainees from Companhia de Saneamento Ambiental do Maranhão-CAEMA, with the aim of better understanding the sense they attribute to the work carried out. To the elaboration of questionnaire, verification and tabulation of data, it was used the Sphinx version 5.1(Program of research and data analysis). It was used as average a scale that goes from 1 to 5 , in which one represents low significance and five greater significance.

It was opted by analyzing four dimensions of the research, as following: "Work is something that", "A work has sense for me when", parts of the dimension "The job conditions must present" and "Work definition elements". From the 44 trainees researched, $65.8 \%$ are female and $43.2 \%$ are male. There is thus small predominance of females.

Table4. Percentile distribution of trainees researched who partially and totally agree with affirmations about: Work is something that

\begin{tabular}{|l|c|c|}
\hline \multicolumn{1}{|c|}{ Work is something that (Affirmations) } & I partially agree and I Totally agree & Average \\
\hline Allows improvement & $95.40 \%$ & 4.7 \\
\hline It is pleasant & $88.70 \%$ & 4.5 \\
\hline It has predetermined schedule & $88.60 \%$ & 4.5 \\
\hline It adds value to something & $84.00 \%$ & 4.4 \\
\hline It offers contribution to the society & $68.20 \%$ & 4.1 \\
\hline It is done in a specific place & $65.90 \%$ & 4.0 \\
\hline Someone tells what must be done & $61.40 \%$ & 3.8 \\
\hline Other persons benefit themselves from it & $59.10 \%$ & 3.8 \\
\hline It allows a belonging feeling & $38.60 \%$ & 3.2 \\
\hline It is mentally demanding & $36.40 \%$ & 3.0 \\
\hline It must be accountable & $34.10 \%$ & 2.8 \\
\hline It is central in my life & $34.10 \%$ & 3.2 \\
\hline It is physically demanding & $25.00 \%$ & 2.8 \\
\hline I carry it out just for salary & $11.30 \%$ & 2.3 \\
\hline That I do for obligation & $6.80 \%$ & 1.8 \\
\hline
\end{tabular}

Source: Research data/2015 
When analyzing Table 4, it is noticed that the dimension "Work is something that" has obtained greater percentile expression. In the affirmative "Allows improvement", with $95.4 \%$ of concordance, remaining, thus, only $4.6 \%$ for other alternatives, which well characterize the trainees in this aspect. The average 4.7 units obtained in this item, in a scale from 1 to 5, confirms supremacy of the trainees concordance with this affirmation. The investigated ones consider work as being pleasant, with the second greater percentage of $88.7 \%$, in average of 4.5 . The variables analyzed is in line with Morin's theory (2001, pp. 14-15), in which he defends, "a work has sense if done efficiently, if conducts something, if benefits other people, if it corresponds to the interests and to the people's competencies, if allows learning, fulfilling, overcoming, if it allows expressing and exercising its power".

The variable "It has predetermined schedule" is presented as a percentage of $88.6 \%$. It can be noticed that people inquired consider work as a learning and improvement source, developed in a propitious environment for its accomplishment. In the variables "It is done in a specific place" and "Someone tells what must be done", the frequencies $65.9 \%$ and $61.4 \%$ are presented in averages of 4.0 and 3.8 units, respectively. These frequencies can be associated to the fact that they all are trainees, because, many times, they do not develop own autonomy at the work environment.

When being inquired about the dimension analyzed, there is a convergence among the following variables: "It adds value to something", with frequency of $84 \%$; "Offers contribution to the society", with percentage of $68.2 \%$; e "Other persons benefit themselves from it", with frequency of $59.1 \%$. It is evidenced that, in the perception of the inquired ones, the labor adds value and benefits other persons.

The research also evinces some dubious aspects relating to this dimension. Therefore, it can be inferred that the assertive, which fit in this premise are: "It allows a feeling of belonging", with percentage of 38.6\%; "It must be accountable" and the work "Is central in my life", with percentages equal to $34.1 \%$ with averages in 2.8 and 3.2, respectively. Because of being a group of trainees, it is noticed that they consider work with little sense of belonging, probably because it does not have durable bond with the organization. The investigated ones little consider work as central part of their lives, maybe because they develop activities parallel to the internship and that have academic bond with other institutions.

When inquired about the variable "Mentally demanded", it has been obtained a percentage of $36.4 \%$. In these circumstances, it is important evaluating that $25 \%$ of the researched consider that the work "is physically demanding". In this context, it is denoted that, probably, the activities that are attributed, in their perception, demands little effort. That is, in the researched people's reading, it can be noticed that these two variables are little important for work developing.

The assertive that obtained smaller percentages, refer to the questionings that can be seen as negative factors to define work and its sense, that is, "I carry it out just for salary" presents frequency of $11.3 \%$ in an average of 2.3. The assertive with smaller frequency has occurred in the variable "That I do for obligation" with percentage of $6.8 \%$ in an average of 1.8 .

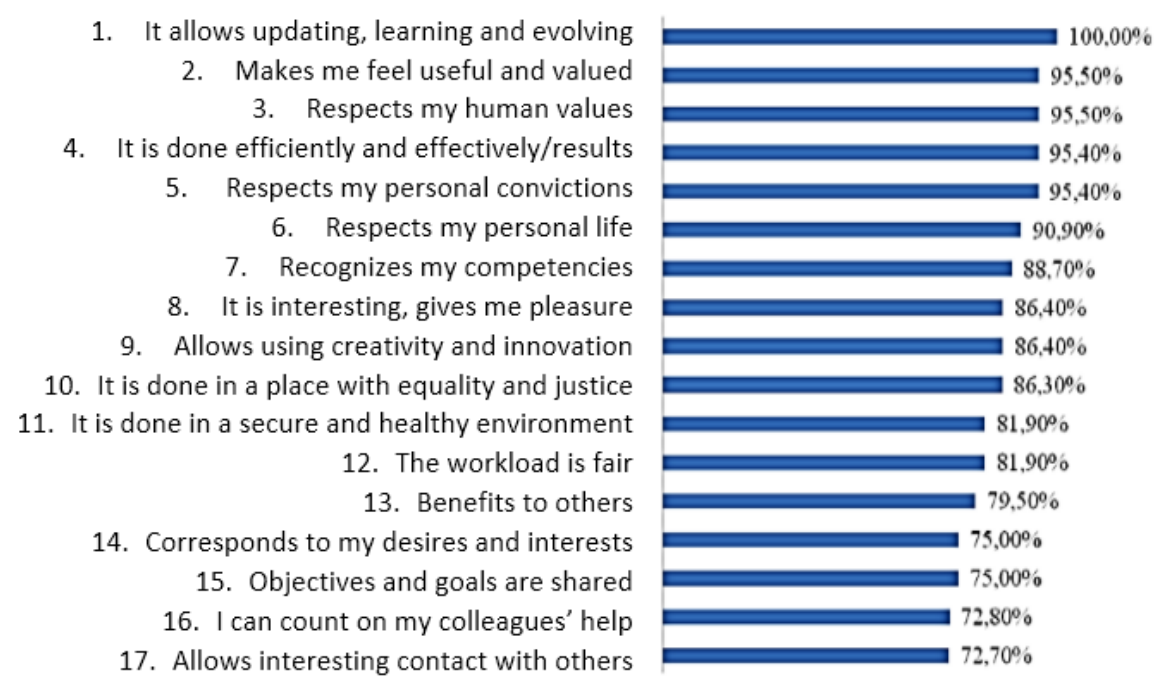

Graph1. Percentage distribution of trainees researched who partially and totally agree with affirmations about: A work makes sense for me when

Source: Research data/2015 
It is noticed that CAEMA's trainees have positive conception about the labor carried out, because the variables of these dimension enable the comprehension for the sense of work. In this context, Ronchi (2010, p. 34) defends, "the sense of work may be associated when it helps individual to discover and form its identity, since the fulfillment feeling is an important factor for giving sense to the work".

When analyzing the dimension "A work has sense for me when", it was noticed that the variables presented percentages superior to $72.7 \%$, considering them as possible definitions about sense of work for the researched. It is verified, based on graph 1, that the affirmative "Allows upgrading and evolving" presents percentage of $100 \%$, becoming the reference variable of the dimension analyzed, demonstrating, in the view of the inquired ones, that the sense of work is totally connected to apprenticeship; in this dynamics, a comparative is done relating to the Morin's (2001, pp. 14-15) theory.

The variables "Makes me feel useful and valued" and "Respects my human values" have obtained percentages equal to $95.5 \%$; in this perspective, it demonstrates that the investigated ones find out sense to the work carried out, when their competencies are recognized. These affirmations are in line with Prestes Motta's (1981, p. 37) theory. He reports that, "the organization reproduces itself, thus, as social system that includes psychological and individual functioning of its members. The organizational system articulates itself, therefore, with the personality system and its participants' values.

When inquired about work and its sense, the variables "Respects my personal convictions" and "It is done efficiently and effectively/results" present the same percentage of $95.4 \%$. It denoted that the results are in line with Morin $(2001$, p. 8$)$ propagates. In the assertive "Respects my personal life", it is noticed a frequency of $90.9 \%$ in which it demonstrated convergence among the variables analyzed. In this context, a comparison is madden between data and theory, in Ronchi's (2010, p. 43) perception, and here he collects that "through its experiences, values, beliefs and suppositions, each individual creates a particular meaning of work".

In the assertive "Recognizes my competencies", it is presented a percentage of $88.7 \%$, in the variables, "It is interesting, and gives pleasure" and "Allows using creativity and innovation", it is noticed a frequency equal to $86.4 \%$. When being inquired about the assertive "It is done in a place of justice and equality", it is presented a percentage of $86.3 \%$. Therefore, it denotes approach among the variables analyzed. In this dynamics, the assertive express, in the view of the investigated ones, that they consider the organizational environment propitious to define a sense to their activities. It is noticed approach between the research and Chanlat's (1996, p. 29) theory, in which it is defined that, "in every social system, the human being enjoys of relative autonomy. Marked by its desires, aspirations and possibilities, it has a level of liberty, knows what can accomplish and which price is willing to pay to get it in the social plan".

In the variables, "It is done in a secure and healthy environment" and "The workload is fair" are presented percentages equal to $81.9 \%$. Then, it is noticed consonance between these variables. When questioned if a work has sense if "Benefits to the others" it is presented a frequency of $79.5 \%$; thus, it is noticed an approach among these variables analyzed. Analyzing the variables with smaller frequency in this dimension: "The objectives and goals are shared", "Corresponds to my desires and interests", "I can count on my colleagues' help" and "Allows interesting contact with others", all them present percentage superior to $72 \%$, showing that these factors, although with smaller frequency, are determining to define the sense of work.

Table5. Percentile distribution of trainees researched who partially and totally agree with affirmations about: The job conditions must present

\begin{tabular}{|l|c|c|}
\hline \multicolumn{1}{|c|}{$\begin{array}{c}\text { The job conditions must present } \\
\text { (Affirmations) }\end{array}$} & $\begin{array}{c}\text { I Partially agree and } \\
\text { I Totally agree }\end{array}$ & Average \\
\hline $\begin{array}{l}\text { If you had much money to live comfortably for the rest of } \\
\text { your life, would you continue working? }\end{array}$ & $75 \%$ & 4.14 \\
\hline $\begin{array}{l}\text { Preferentially a pleasant organizational environment, even } \\
\text { with a salary under average paid for this function. }\end{array}$ & $40.9 \%$ & 3.30 \\
\hline $\begin{array}{l}\text { Preferentially a good salary, even in an uncomfortable } \\
\text { organizational environment. }\end{array}$ & $34.1 \%$ & 3.27 \\
\hline
\end{tabular}

Source: Research data/2015 
The table 5 demonstrates three variables that are connected to the dimension "The job conditions must present"; on the basis on this foregoing, Ronchi (2015) defends that the quality of life at work is a comprehensive and committed understanding of life conditions at work, which includes welfare aspects, health guarantee and physical, mental and social security, and qualification to carry out tasks with security and good use of personal energy.

It is analyzed data from the questioning, "If you had much money to live comfortably for the rest of your life, would you continue working?" presents concordance of $75 \%$, in an average of 4.14 , in a scale from 1 to 5 points. This data demonstrate that the researched ones see positive bond among the conditions that the job presents. The assertive "Preferentially a pleasant organizational environment, even with a salary under average paid for this function" with percentage of $40.9 \%$ and "Preferentially a good salary, even in an uncomfortable organizational environment", with smaller frequency of the dimension researched of $34.1 \%$, can be compared. It demonstrates, thus, that the organizational environment is considered as factor that influences the sense that the trainees attribute to the work.

Table6. Percentile distribution of trainees researched who partially and totally agree with affirmations about: Elements of work definition

\begin{tabular}{|l|c|c|}
\hline Elements ofwork definition. (Affirmations) & $\begin{array}{c}\text { I Partially agree and } \\
\text { I Totally agree }\end{array}$ & Average \\
\hline Work is what allows me improving & $90.9 \%$ & 4.45 \\
\hline Work adds value to something & $77.3 \%$ & 4.11 \\
\hline Work can be considered central to the everyday actions & $61.4 \%$ & 3.73 \\
\hline The work I do contributes to the society & $59 \%$ & 3.7 \\
\hline Work is what I do in a specific place & $54.6 \%$ & 3.91 \\
\hline Work is part of my tasks & $54.6 \%$ & 3.66 \\
\hline My work makes me have a feeling of connection while I do it & $47.7 \%$ & 3.52 \\
\hline Work is when I do in a certain moment & $34.1 \%$ & 3.11 \\
\hline My work is mentally demanding & $31.9 \%$ & 2.8 \\
\hline Work is when others benefit themselves & $31.8 \%$ & 3.34 \\
\hline Work is the most important part of my life & $22.8 \%$ & 2.68 \\
\hline Work is something that I receive money to carry out & $18.2 \%$ & 2.41 \\
\hline Work is when I have to render accounts & $18.2 \%$ & 2.48 \\
\hline Work is when someone tells me what to do & $13.7 \%$ & 2.43 \\
\hline The work is physically demanding & $11.4 \%$ & 2.32 \\
\hline Work is when I am obligated to do it & $9.1 \%$ & 1.82 \\
\hline Working is not pleasant, if I could I would not work & $6.8 \%$ & 1.75 \\
\hline
\end{tabular}

Source: Research data/2015

The Table6 presents the dimension "Elements that define work", in which the investigated ones elect some of the variables with more elevated percentages. The variable "Work is something that allows me improving" presents the greater frequency of the dimension with percentage of $90.9 \%$ in an average of 4.5. The variables "Work adds value to something" and "Work can be considered central to the everyday actions" present percentages of $77.3 \%$ and $61.4 \%$, being the second and third references from the researched dimension. In this context, it is noticed that the investigated consider the continuous apprenticeship as an element that can define work, since the work environment provides an evolution for this individual.

When the investigated about the assertive "The work I do contributes to the society", there is concordance of $59 \%$, and it is noticed a relation between the research and Ronchi's (2010) theory, because he explains that the work can be considered as one of the fundamental means that declares the individual to its human-social nature. The variables "Work is what I do in a specific place" and "Work is part of my tasks" present percentage equal to $54.6 \%$ with averages in 3.91 and 3.66, dividing, thus, the trainees" opinions. When being inquired about the variables "My work makes me have a feeling of connection while I do it" and "My work is mentally demanding" with $47.7 \%$ and $31.9 \%$, respectively, the trainees were also divided.

The variable "Work is the most important part of my life", with concordance of $22.8 \%$ and average of 2.68 units, shows that the investigated ones do not define work, necessarily, as essential part of their lives. When inquired about the variable "Work is when others benefit themselves", the acceptance of this information from only $31.8 \%$ of the trainees fill exactly what Morin (2001) propagates. 
The variation of assertive, with lower percentage frequency, is between $6.8 \%$ and $18.2 \%$ in the investigated people's view. When questioned about the variables "Work is something that I receive money to carry out" e "Work is when I have to render accounts", with $18.2 \%$ each, the vast majority of the trainees demonstrate that they do not see work only by these perspectives. The low percentages of concordance for affirmations "Work is when someone tells me what to do" (13.7\%), "Work is physically demanding" (11.4\%), "Work is when I am obligated to do it" $(9.1 \%)$ and "Work is not pleasant, if I could I would not work" (6.8\%)show that the expressive majority of interviewed ones is contrary to all these information, having a positive and quite different sense for the work.

\section{Conclusion}

Along the study, considerations were done about the sense of work in the view of CAEMA's trainees. It was pursued to understand how the sense of work may influence the individuals inserted in the organizational context, because this sense is surrounded of aspects, which may cause pleasure and suffering, thereof may be them strong influencers in the health and quality of life at the labor environment. When developing a research, it is important to evidence that all they present limitations. In this article, other information were investigated, however, according to the limits of space, it was not possible presenting all. This research is a transversal cut, that is, at another certain moment, different results may arise; other limitation of this research may be associated to the fact that they are trainees. Thus, it can be inferred that, theoretically, they do not feel totally as professionals in the organizational context.

The multiple facets, that involve the work, are perceived in different ways, taking into consideration that each subject develops different sensations. On the basis on the foregoing, the present article has evidenced diverse dimensions about the sense of work and organizational implications in this construct, with the aim of better understand the investigated ones' positioning about the phenomenon in question. Therefore, then, it is noticed that the organization is great influencer of the sense they attribute to the work, because there was strong concentration of the investigated ones' opinion in the variables that refer to the recognition of activities carried out, because they feel useful and valued.

It was found that trainees carry out the work with compromise, since the research presented low percentage when being inquired if they carry out activities for obligation. It can be inferred, thus, that the investigated ones have positive conception regarding to the relation among activities carried out and the organization. It was still verified that, for the majority of the investigated ones, they worry more about a pleasant labor environment than receiving a high salary and not having work conditions. It was observed, therefore, that a work has sense for the researched ones when it is related to the obtaining of new knowledge, apprenticeship and e evolution, where the work environment respects convictions and personal life; thus, the organizational environment is seen as a place of justice and equality, thereof may be responsible for to proportionate the individual a vision about the phenomenon.

In these conditions, it was evidenced that the inquired ones carry out their activities with satisfaction, because the definition of work goes beyond its attributions, since they do not carry out their tasks due mere obligation; therefore, they little consider activities they develop as a factor of physical exhaustion. Taking into account, from the trainees' perception, that they visualize the work as positive aspect and aggregator of values, it is collected that they be factors that can add better experiences.

Bearing in mind that the investigated ones consider the work pleasant, it is added value, because they elect these factors as elements of work definition, it is observed a compromise of the trainees when carrying out activities.

The trainee function may be an aspect that may influence the sense of work, because they are not turned permanent professionals, because they could develop a differentiated perception about the work. On the basis on the foregoing, from the investigated ones' perception, it is possible, thus, concluding that they define the sense of work as something that is connected to a propitious environment to acquire new knowledge, since they presented a high percentage regarding to the sense of work and the variables that correlate labor and apprenticeship, in which the activities carried out have a sense for upgrading, learning and evolving concerning to the perception of the organizational context. 


\section{REFERENCES}

AUBERT, N. A neurose profissional. RAE - Revista de Administração de Empresas. São Paulo, 33, Jan/ Fev 1993.

BASTOS, A.V.B., PINHO, A.P.M.; COSTA, C.A. Significado do trabalho: um estudo entre trabalhadores inseridos em organizações formais. RAE - Revista de Administração de Empresas. São Paulo, V.35, n6. Nov/Dez 1995.

BAUMAN, Z. Modernidade Líquida. Rio de Janeiro: Jorge Zahar. Ed, 2001.

COUTINHO, M.C. Sentidos do trabalho contemporâneo: as trajetórias identitárias como estratégia de investigação. Cadernos de Psicologia Social do Trabalho. v.12, n. 2, 2009.

CHANLAT, J.F. Por uma antropologia da condição humana nas organizações. In: O indivíduo na organização: dimensões esquecidas. Vol I. 3. Ed. São Paulo: Atlas, 1996.

CLEGG, S. Poder, linguagem e ação nas organizações, In: $\mathbf{O}$ indivíduo na organização: dimensões esquecidas. Vol I. 3. Ed. São Paulo: Atlas, 1996.

DEBORD, G. A Sociedade do Espetáculo. Rio de Janeiro: Contraponto, 1997.

DEJOURS, C. A loucura do trabalho: estudo de psicologia do trabalho. São Paulo: Cortez - Oboré, 1992.

A carga psíquica do trabalho. In: Psicodinâmica do trabalho: contribuição da escola dejouriana à analise da relação prazer, sofrimento e trabalho. São Paulo: Atlas, 1994.

. Trabalho e saúde mental: da pesquisa à ação. In: Psicodinâmica do trabalho: contribuição da escola dejouriana à analise da relação prazer, sofrimento e trabalho. São Paulo: Atlas, 1994.

. Subjetividade, trabalho e ação. Revista Produção, São Paulo, v. 14, nº 3, Set/Dez, 2004.

ABDOUCHELI, E.; JAYET, C. Itinerário Teórico em Psicopatologia do trabalho. In: Psicodinâmica do trabalho: contribuição da escola dejouriana à analise da relação prazer, sofrimento e trabalho. São Paulo: Atlas, 1994.

FREITAS, M.E. Contexto Social e Imaginário Organizacional e Moderno. RAE - Revista de Administração de Empresas. v. 40 n. 2 Abr./Jun. 2000.

GUIMARÃES, L.A.; SIEGRIST, J.; MARTINS, D.A. Modelo teórico de estresse ocupacional: desequilíbrio entre esforço - recompensa no trabalho (ERI). In: Série saúde mental e trabalho. Vol. II. São Paulo: Casa do Psicólogo, 2004.

GAULEJAC, V. Gestão como doença: ideologia, poder gerencialista e fragmentação social. Aparecida: Ideias e Letras, 2007.

LADEIRA, M.B. O processo de stress ocupacional e a psicopatologia do trabalho. Revista de Administração, São Paulo, v. 31, nº 1. Jan/Mar 1996.

LIMA, M.P.; TAVARES, N.V.; BRITO, M.J.; CAPPELLE, M.C.A. O sentido do trabalho para pessoas com deficiência. RAM- Revista de Administração Mackenzie. Vol. 12, nº 2. São Paulo. Mar/Abr. 2013.

LIPOVETSKY, G. Os tempos hipermodernos. São Paulo: Editora Barcarolla, 2004.

MORIN, E. M. Os sentidos do trabalho. RAE - Revista de Administração de Empresas, no 3, vol. 41, São Paulo 2001.

PRESTES MOTTA, F.C. O Poder Disciplinar nas Organizações Formais. RAE - Revista de Administração de Empresas. Rio de Janeiro. Out/Dez 1981.

QUIVY, R.; CAMPENHOUDT, L.V. Manual de investigação em ciências sociais. Lisboa: Gradiva, 2008.

RONCHI, C.C. Sentido do trabalho: saúde e qualidade de vida. Curitiba: Juruá, 2010.

. Qualidade de vida e trabalho: fatores psicossociais e da organização. Curitiba: Juruá, 2015.

SANTOS, L.C.; GOULART JR, E.; CANÊO, L.C.; LUNARDELLI, M.C.F.; CARVALHO, P.L. Psicologia e profissão: neurose profissional e a atuação do psicólogo organizacional frente a questão. Psicologia Ciência e Profissão, 2010.

SAMPAIO, A.L.P.; GUIMARÃES, L.A.M. Modelo teórico esforço-distress de Marianne Frankenhauser e o conceito de carga de trabalho. In:Série saúde mental e trabalho. Vol. II. São Paulo: Casa do Psicólogo, 2004. 
THIRY-CHERQUES, H.R. Sobrevivência ao trabalho. Rio de Janeiro: Editora FGV, 2004.

TOLFO, S.R.; PICCININI, V. Sentidos e significados do trabalho: explorando conceitos, variáveis e estudos empíricos brasileiro. Psicologia \& Sociedade; 19, Ed. Especial 1, 2007.

; COUTINHO, M.C.; BAASCH, D.; CUGNIER, J.S. Sentidos y significados del trabajo: un análisis con base en diferentes perspectivas teórico-epistemológicas en Psicología. Univ. Psychol. V. 10. No. 1. pp. 175-188. ENE-Abr, 2011. 